\title{
Water and Fertilizer Use Efficiency in Subirrigated Containerized Tomato
}

\author{
Ariel Méndez-Cifuentes ${ }^{1}$, Luis Alonso Valdez-Aguilar ${ }^{1, *}$, Martín Cadena-Zapata ${ }^{2}$, \\ José Antonio González-Fuentes ${ }^{1}$, José Alfredo Hernández-Maruri ${ }^{1}$ \\ and Daniela Alvarado-Camarillo ${ }^{3}$ \\ 1 Departamento de Horticultura, Universidad Autónoma Agraria Antonio Narro, Saltillo 25315, Coahuila, \\ Mexico; mendezc.ariel@gmail.com (A.M.-C.); jagf@uaaan.edu.mx (J.A.G.-F.); \\ alfredo.hernandezm@uaaan.edu.mx (J.A.H.-M.) \\ 2 Departamento de Maquinaria Agrícola, Universidad Autónoma Agraria Antonio Narro, Saltillo 25315, \\ Coahuila, Mexico; martin.cadena@uaaan.edu.mx \\ 3 Departamento de Ciencias del Suelo, Universidad Autónoma Agraria Antonio Narro, Saltillo 25315, \\ Coahuila, Mexico; daniela.alvaradoc@uaaan.edu.mx \\ * Correspondence: luisalonso.valdez@uaaan.edu.mx
}

Received: 19 March 2020; Accepted: 3 May 2020; Published: 7 May 2020

\begin{abstract}
Greenhouse cultivation is highly efficient in the use of water and fertilizers. However, due to intensive production, the greenhouse industry applies ample amounts of water and fertilizers. An alternative to minimize water and nutrient loss is zero-leaching systems, such as closed-loop subirrigation. The objective of the present study was to compare the water and fertilizer use efficiency in containerized tomato plants grown in a subirrigation system and a drip irrigation system. Subirrigated plants exhibited lower biomass than drip-irrigated plants. However, the amount of nutrient solution required to restore evapotranspirated water was lower in subirrigation. The yield was marginally decreased in subirrigated plants compared to drip-irrigated plants. The amount of nutrient solution required to produce $1 \mathrm{~kg}$ of fresh tomatoes was $22 \mathrm{~L}$ in subirrigation, whereas in drip irrigation, plants demanded $41 \mathrm{~L}$. The total nitrogen applied through the nutrient solution was $75 \%$ lower in subirrigation than in drip irrigation, while the phosphorus, potassium, calcium and magnesium applied was $66 \%, 59 \%, 70 \%$ and $74 \%$ lower, respectively. We concluded that the subirrigation system proved to be more water- and nutrient-efficient than the drip irrigation system due to the zero leaching of the nutrient solution, the lower number of irrigation events required and the lower nutrient demand of plants.
\end{abstract}

Keywords: zero-leaching watering systems; drip irrigation; greenhouse vegetable crops; water scarcity

\section{Introduction}

Water is one of the most important resources. It is used for household and industrial consumption, as well as for agricultural production [1]. Agricultural production systems are the largest consumers of water [2-4]; the irrigation of agricultural crops has allowed for the raising of yields and the stabilizing of food production and prices, which in turn has permitted the achievement of food security in many countries [5]. Groundwater is by far the main source of potable water (at least 50\%) and water for agricultural irrigation (43\%) [6]. Nonetheless, excessive use of water because of inadequate irrigation practices has caused overexploitation of aquifers, reduced water quality due to pollution and decreased groundwater tables $[7,8]$.

Greenhouse cultivation provides food products of high quality all year round and, in terms of yield and gross income, it is highly efficient in the use of water and fertilizers due to the decrease in 
potential evaporation and the application of advanced irrigation technologies, such as drip irrigation and hydroponics [9]. However, in spite of its high efficiency, due to its intensive use and high yields, the greenhouse industry applies more water and fertilizers on a surface area basis compared to any other agricultural system, greatly contributing to the depletion and pollution of water reservoirs. Reducing the water and fertilizer amounts used for greenhouse production is thus important due to availability and pollution concerns. In fact, greenhouse growers fear the scarcity of water of good quality much more than its cost [9]. A strategy to further increase water and fertilizer use efficiency in greenhouse production is to adopt cultivation systems that collect and reuse irrigation water by using closed-loop irrigation systems [10-12]. Soil pollution in greenhouses is also an issue of utmost importance. In Europe, for example, concentrations of $\mathrm{NO}_{3}{ }^{-}$-nitrogen (N) up to $2000 \mathrm{~kg}$ $\mathrm{ha}^{-1}$ were recorded in a $100 \mathrm{~cm}$ soil depth underlying commercial greenhouses [13], while in the United States, reports indicated concentrations higher than $2300 \mathrm{~kg} \mathrm{ha}^{-1}$ in the soil under decades-old greenhouses [14].

Vegetable production under controlled environment systems has allowed yield and quality increases due to the higher fertilizer rates and water inputs [15]; for example, $\mathrm{N}$ rates for some containerized nursery plants range from 1067 to $2354 \mathrm{~kg} \mathrm{ha}^{-1}$ per year, which is $10-15$ times higher than that recommended for field crops [16].

Common practices for greenhouse production include surface irrigation systems with no recirculation of the nutrient/fertigation solution, which is not environmentally friendly $[17,18]$. The loss of water and nutrients in such irrigation systems is caused by high leaching rates as the water supplied surpasses the water retention capacity of the growing medium [18,19]. Unfortunately, high leaching rates are required to avoid salt buildup in the growing media. Combining high fertilizer rates with an inadequate irrigation system results in increased leaching, and thus, in increased groundwater pollution [20]. Thus, the efficient use of water is one of the fundamental factors to guarantee food production [21].

Establishing innovative irrigation water management may contribute to the mitigation of negative issues related to climate change [22]. An alternative to minimize water and nutrient loss to the environment for soilless cultivation of vegetable species is zero-leaching systems, such as subirrigation [23-25]. Closed irrigation systems are an interesting and promising method to maximize water and fertilizer use efficiency compared to conventional open irrigation systems $[2,10,23]$, as the nutrient solution that is not retained by the growing medium is recirculated for reuse in the next irrigation event $[15,17,26-28]$.

Subirrigation systems have been assessed for containerized greenhouse ornamental plants, which have demonstrated increased water and nutrient efficiency $[15,29,30]$ and increased growth [12]. Nevertheless, little attention has been paid to the use of subirrigation for containerized vegetable species [31-33] such as greenhouse tomato. The objective of the present study was to define water and fertilizer use efficiency in containerized tomato grown in a subirrigation system.

\section{Materials and Methods}

\subsection{Cultural Conditions and Plant Material}

The experiment was conducted in a greenhouse at Universidad Autónoma Agraria Antonio Narro, in Northeast Mexico ( $25^{\circ} 23^{\prime} 42^{\prime \prime}$ N Lat., $100^{\circ} 59^{\prime} 57^{\prime \prime}$ W Long., $1743 \mathrm{~m}$ above sea level). Weather data were collected from a weather station located in the greenhouse. Mean maximum, mean minimum and mean temperature for the study duration were $25.7^{\circ} \mathrm{C}, 14.4^{\circ} \mathrm{C}$ and $20.1{ }^{\circ} \mathrm{C}$, respectively, while maximum, minimum and mean relative humidity were $92 \%, 43 \%$ and $68 \%$, respectively. Mean seasonal photosynthetically active radiation was $389 \mu \mathrm{mol} \mathrm{m}^{-2} \mathrm{~s}^{-1}$.

Solanum lycopersicum L. cv. Climstar $20 \mathrm{~cm}$ tall transplants with two fully expanded leaves were planted on 26 August 2017, into 13 L black polyethylene containers (one plant per container) filled with a mixture of sphagnum moss, coconut fiber and perlite $(40 \%, 40 \%, 20 \% v / v)$ to a height of $27 \mathrm{~cm}$. Initial medium $\mathrm{pH}$ and electrical conductivity (EC) were 5.7 and $0.8 \mathrm{dS} \mathrm{m}^{-1}$, respectively. 


\subsection{Irrigation Systems}

In this experiment, a subirrigation system was designed in order to compare the water and fertilizer use efficiency against drip irrigation. The subirrigation system consisted of rigid plastic trays/troughs $(69 \times 39 \times 16 \mathrm{~cm}$; length, width and height $)$ with two 1-plant containers each. Containers were placed $30 \mathrm{~cm}$ apart within the row, and rows were kept $120 \mathrm{~cm}$ apart. Each tray/trough had a system of polyvinyl chloride pipes and valves for irrigation and drainage of the corresponding nutrient solution, which was pumped with a $\frac{1}{4}$ HP pump.

Subirrigation started when the growing medium registered a moisture tension of $10 \mathrm{KPa}$ measured with a tensiometer (Irrometer Model MLT, Riverside, CA, USA), with a flooding depth and duration of $15 \mathrm{~cm}$ and $30 \mathrm{~min}$, on which the containers remained standing in the nutrient solution. The unabsorbed solution was drained back into a $200 \mathrm{~L}$ storage tank for reuse in the following irrigation event and renewed every 15 days. The $\mathrm{pH}$ of the nutrient solution was adjusted to $6.0 \pm 0.1$ prior to irrigation with $\mathrm{H}_{2} \mathrm{SO}_{4}(0.1 \mathrm{~N})$. The evapotranspirated nutrient solution was replenished with fresh nutrient solution to complete the initial volume of the storage tank. The drip surface irrigation system consisted of two emitters dispensing a total of $2 \mathrm{~L} \cdot \mathrm{h}^{-1}$ of nutrient solution per container, and irrigation was conducted when the substrate moisture tension reached $10 \mathrm{KPa}$, with enough solution to achieve a $30 \%$ leaching fraction. The experimental unit for the subirrigation treatment consisted of two containers (i.e., two plants) placed on a single tray/trough. The drip irrigation treatment also had two one-plant containers per replication.

\subsection{Nutrient Solutions}

Basic nutrient solution contained (meq $\mathrm{L}^{-1}$ ): $14 \mathrm{NO}_{3}{ }^{-}, 2 \mathrm{H}_{2} \mathrm{PO}_{4}{ }^{-}, 8 \mathrm{SO}_{4}{ }^{2-}, 11 \mathrm{Ca}^{2+}, 9 \mathrm{~K}^{+}$and 4 $\mathrm{Mg}^{2+}\left(\mathrm{EC}=2.4 \mathrm{dS} \mathrm{m}^{-1}\right)$. During the vegetative phase, the basic nutrient solution was applied at $120 \%$ concentration. However, from the blooming of the first to the third truss, the concentration of the basic nutrient solution was decreased to $70 \%\left(\mathrm{EC}=1.7 \mathrm{dS} \mathrm{m}^{-1}\right)$, and from the third to the fifth truss it was at $50 \%\left(\mathrm{EC}=1.2 \mathrm{dS} \mathrm{m}^{-1}\right)$. The fertilizer-grade salts used for preparation of the nutrient solutions included: $5\left[\mathrm{Ca}\left(\mathrm{NO}_{3}\right)_{2} \cdot 2 \mathrm{H}_{2} \mathrm{O}\right] 1 \mathrm{NH}_{4} \mathrm{NO}_{3}, \mathrm{MgSO}_{4} \cdot 7 \mathrm{H}_{2} \mathrm{O}, \mathrm{KNO}_{3}, \mathrm{~K}_{2} \mathrm{SO}_{4}, \mathrm{KCl}, \mathrm{HNO}_{3}$ and $\mathrm{H}_{3} \mathrm{PO}_{4}$. Micronutrients were provided as Fe-EDTA, Zn-EDTA. Cu-EDTA, Mn-EDTA, B and Mo at (in $\mathrm{mg} \mathrm{L}^{-1}$ ): 3.0, 0.2, 0.1, 1.4, 0.3 and 0.1 , respectively.

\subsection{Plant Growth, Yield and Mineral Composition}

The harvest of fruits started 120 days after transplanting and was completed when the study was concluded (160 days after transplanting). The fruit was considered ready for harvest when $80 \%$ of the pericarp was red; the fresh fruit yield was calculated on a total yield basis. At experiment termination, whole plants were harvested and the roots were washed with tap water to remove excess substrate; the substrate was divided in three layers: bottom, medium and top layers ( 0 to 8,8 to 16 and 16 to $25 \mathrm{~cm}$ of the root ball, respectively). The shoot was separated into stems, leaves and all the fruits harvested, which were then, along with the roots, dried in an oven at $70{ }^{\circ} \mathrm{C}$ for $72 \mathrm{~h}$ prior to measuring dry weight.

\subsection{Tissue Mineral Analysis and Substrate $\mathrm{pH}$ and EC}

Dry plant tissues (root, shoot and fruit) were ground to pass a 20-mesh sieve (Thomas-Wiley Mill Co., Philadelphia, PA). Dry ground tissues were analyzed for total $\mathrm{N}$ concentration utilizing Kjeldhal's procedure [34], while phosphorus $(\mathrm{P})$, potassium $(\mathrm{K})$, calcium $(\mathrm{Ca})$ and magnesium $(\mathrm{Mg})$ concentrations were determined in previously digested ground tissues (2:1 mixture of $\mathrm{H}_{2} \mathrm{SO}_{4}: \mathrm{HClO}_{4}$ and $2 \mathrm{~mL}$ of $30 \%$ $\mathrm{H}_{2} \mathrm{O}_{2}$ ) with an Inductively Coupled Plasma Emission Spectrometer (ICP-AES, model Liberty, VARIAN, Santa Clara, CA) [35]. Macronutrients accumulated in the entire plant were calculated considering their concentration in the roots, shoot and fruits and the dry weight of each plant part.

Substrate $\mathrm{pH}$ and $\mathrm{EC}$ were measured in an air-dried sample from the three medium layers using the 1:2 dilution method [36]. The 1:2 mixture was allowed to sit for 60 minutes and then it was filtered. The $\mathrm{pH}$ and EC were measured using a portable ionometer (Horiba LAQUA Twin). 


\subsection{Water and Nutrient Use Efficiency}

Water consumed by plants was measured indirectly in both irrigation systems. In subirrigation, the volume of water retained by the growing medium was calculated by measuring the nutrient solution depleted from the tray/trough at flooding termination, while in drip-irrigated plants, it was calculated by measuring the solution dispensed through the emitters when the leaching fraction was achieved. Water consumed throughout the study was used to calculate the water use efficiency in terms of total fresh fruit production (liters of water per kilogram of fresh fruit produced) and total evapotranspirated water (liters of water evapotranspirated per plant throughout study duration).

\subsection{Statistical Design and Analysis of Irrigation Method Effect}

The experiment was set in a randomized complete blocks design with two treatments: subirrigation and drip irrigation systems, with six two-plant replications per treatment. Data were analyzed with ANOVA, and Tukey's multiple mean comparison test $(p \leq 0.05)$ when appropriate, using $R$ Studio (v. 3.4.2.) $[37,38]$.

\section{Results}

Subirrigation caused lower plant biomass production than in drip-irrigated plants, which was due to a decrease in root and leaf growth as suggested by their lower dry weight (Table 1). Stem and fruits dry weights were similar for plants in both irrigation systems (Table 1). Fruit yield was slightly but significantly decreased $(9.5 \%)$ in subirrigated plants (Figure 1 ).

Table 1. Dry weight of plant parts of tomato (Solanum lycopersicum L.) grown in two irrigation systems.

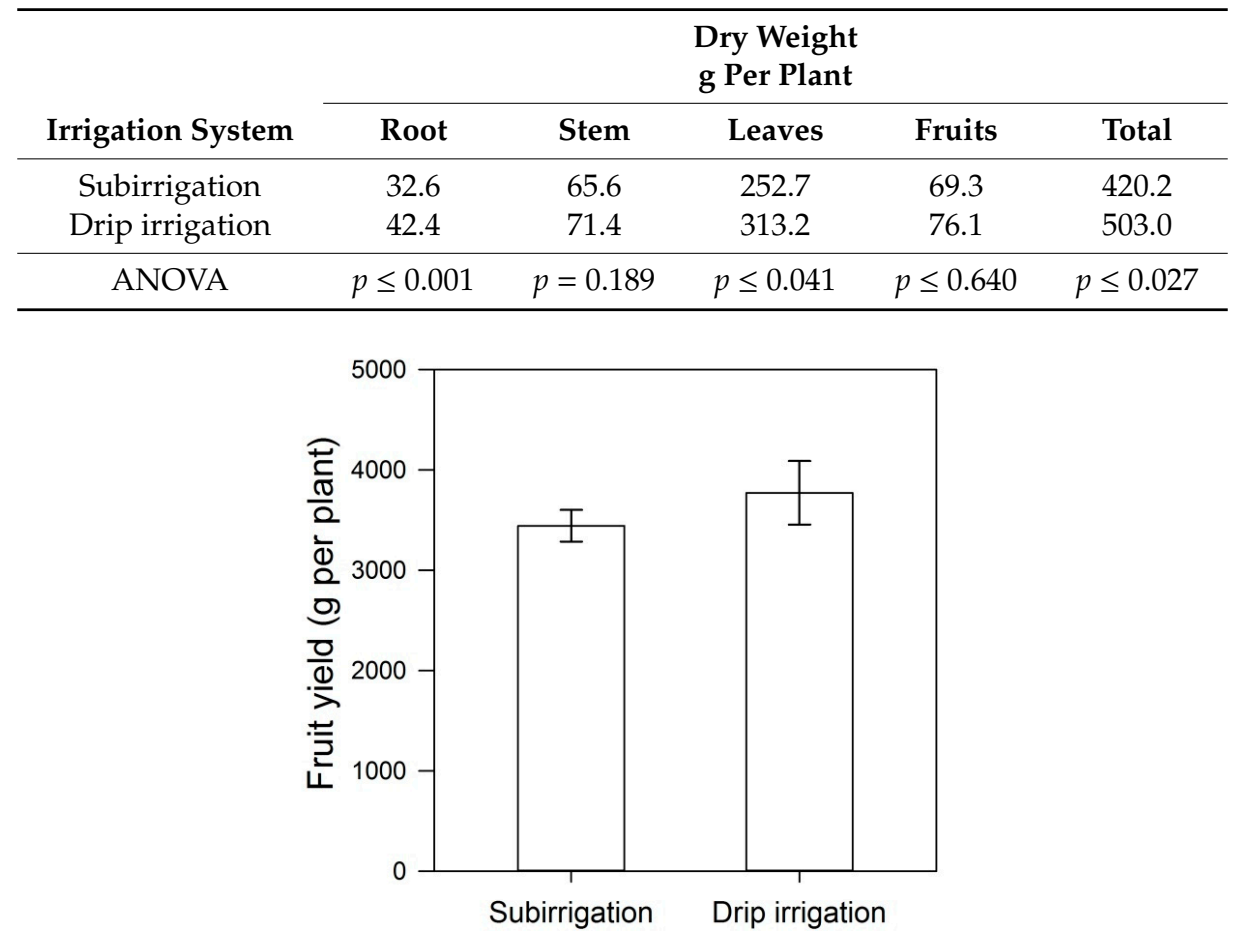

Figure 1. Fresh fruit yield of tomato (Solanum lycopersicum L.) plants grown in two irrigation systems. Means were significantly different according to ANOVA $(p \leq 0.018)$.

Substrate $\mathrm{pH}$ was lower while the EC was higher when subirrigation was applied (Table 2). Nonetheless, when averaged across both irrigation systems, the $\mathrm{pH}$ was higher in the middle and bottom layers of the growing medium, while the EC was higher in the top layer (Table 2).

The amount of nutrient solution required to restore evapotranspirated water was predominantly lower in subirrigation in most of the irrigations conducted throughout the experiment, while in drip irrigation, plants demanded twice as much solution (Figure 2). Throughout the study, plants in subirrigation required 38 irrigations whereas in drip irrigation there were 40 irrigation events (Figure 2). 
Table 2. Growing medium $\mathrm{pH}$ and electrical conductivity (EC) at experiment termination as affected by two irrigation systems and the root ball substrate layer of tomato (Solanum lycopersicum L.) plants.

\begin{tabular}{|c|c|c|}
\hline Irrigation Systems & $\mathrm{pH}$ & $\mathrm{EC}\left(\mathrm{dS} \mathrm{m}^{-1}\right)$ \\
\hline Subirrigation & $6.65 b$ & $2.33 a$ \\
\hline Drip irrigation & $6.77 \mathrm{a}$ & $0.64 b$ \\
\hline \multicolumn{3}{|l|}{ Growth medium layer } \\
\hline Top & $6.18 b$ & $2.53 a$ \\
\hline Middle & $6.98 \mathrm{a}$ & $0.84 \mathrm{c}$ \\
\hline Bottom & $6.95 a$ & $1.07 \mathrm{~b}$ \\
\hline ANOVA Irrigation systems & $p=0.014$ & $p \leq 0.001$ \\
\hline Medium layer & $p=0.031$ & $p \leq 0.001$ \\
\hline
\end{tabular}

Means followed by different letters indicate significant effects according to Tukey's multiple comparison test $(p \leq 0.05)$.

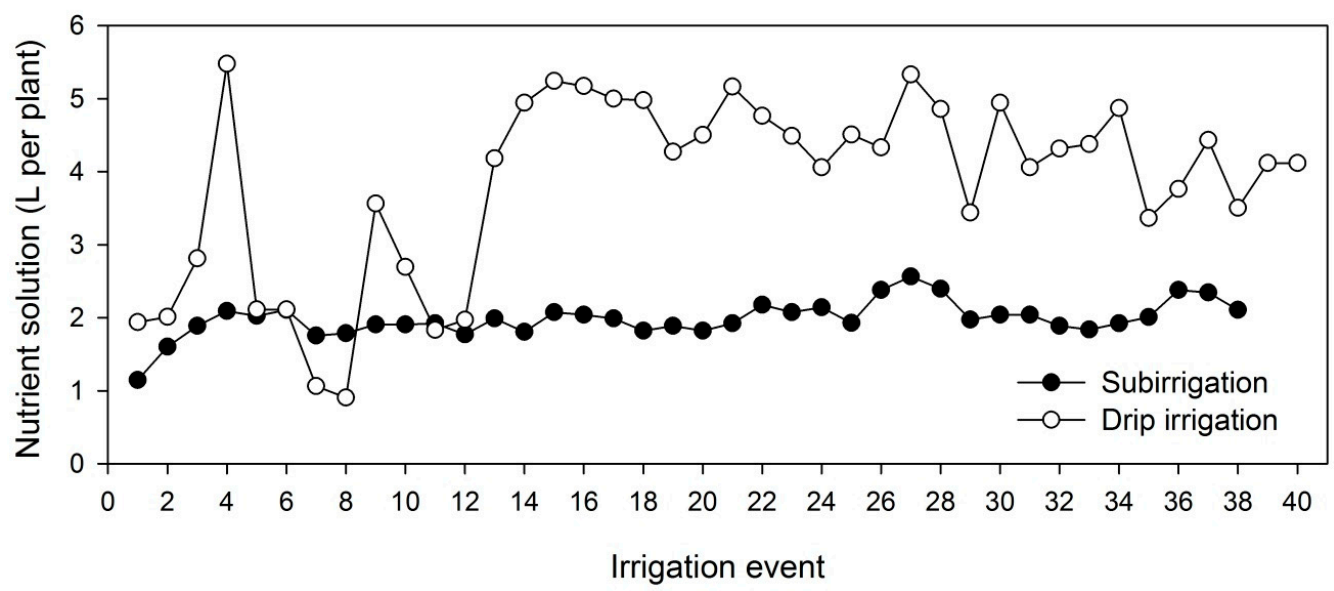

Figure 2. Volume of nutrient solution required at every irrigation event to bring the growing medium to container capacity in containerized tomato (Solanum lycopersicon L.) plants.

Water use efficiency was higher with subirrigation as plants demanded $22 \mathrm{~L}$ of water to produce $1 \mathrm{~kg}$ of fresh tomato fruit (Figure 3). In contrast, with drip irrigation, plants required $41 \mathrm{~L}$ per $\mathrm{kg}$ (Figure 3). In terms of total water consumed, water use efficiency was also higher with subirrigation as plants demanded $76 \mathrm{~L}$ per plant, while with drip irrigation, plants demanded $154 \mathrm{~L}$ per plant (Figure 3).

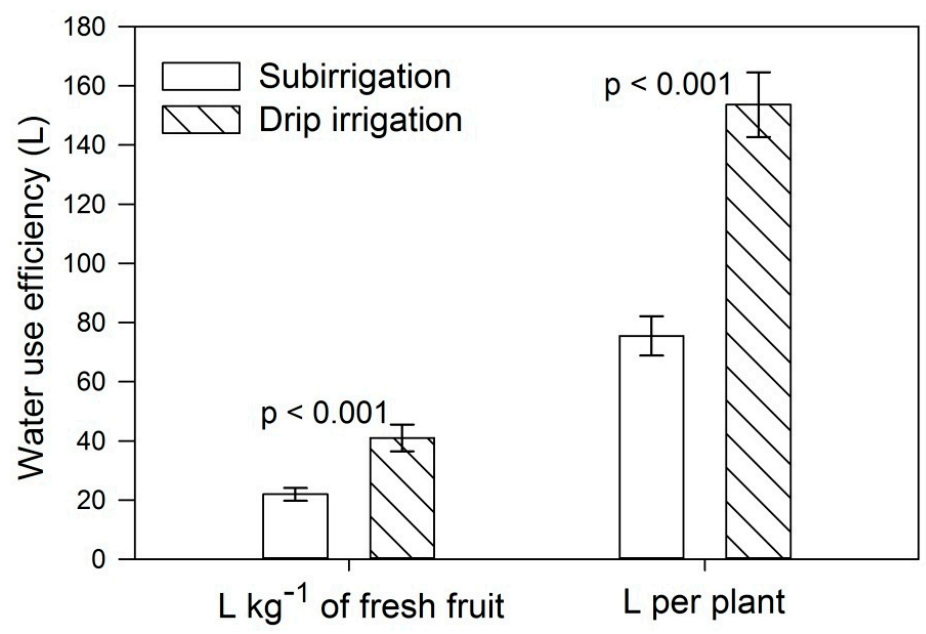

Figure 3. Water use efficiency in terms of fresh fruit production and total evapotranspirated water in containerized tomato (Solanum lycopersicon L.) plants grown in two irrigation systems. Means were significantly different according to ANOVA. 
The amounts of N, P, K, Ca and Mg applied through the nutrient solution during the whole experiment were markedly decreased in the subirrigation system (Figure 4). Total $\mathrm{N}$ applied was $75 \%$ lower in subirrigation than in drip irrigation (Figure 4a), while the $\mathrm{P}, \mathrm{K}, \mathrm{Ca}$ and $\mathrm{Mg}$ applied decreased by $66 \%, 59 \%, 70 \%$ and $74 \%$, respectively (Figure $4 \mathrm{~b}-\mathrm{e}$ ). Nonetheless, $\mathrm{N}$ accumulated in plant tissues at experiment termination was $60 \%$ lower in subirrigated plants (Figure $4 \mathrm{a}$ ), while $\mathrm{P}, \mathrm{K}, \mathrm{Ca}$ and $\mathrm{Mg}$ accumulation was $61 \%, 47 \%, 66 \%$ and $56 \%$ lower, respectively (Figure $4 \mathrm{~b}-\mathrm{e}$ ).

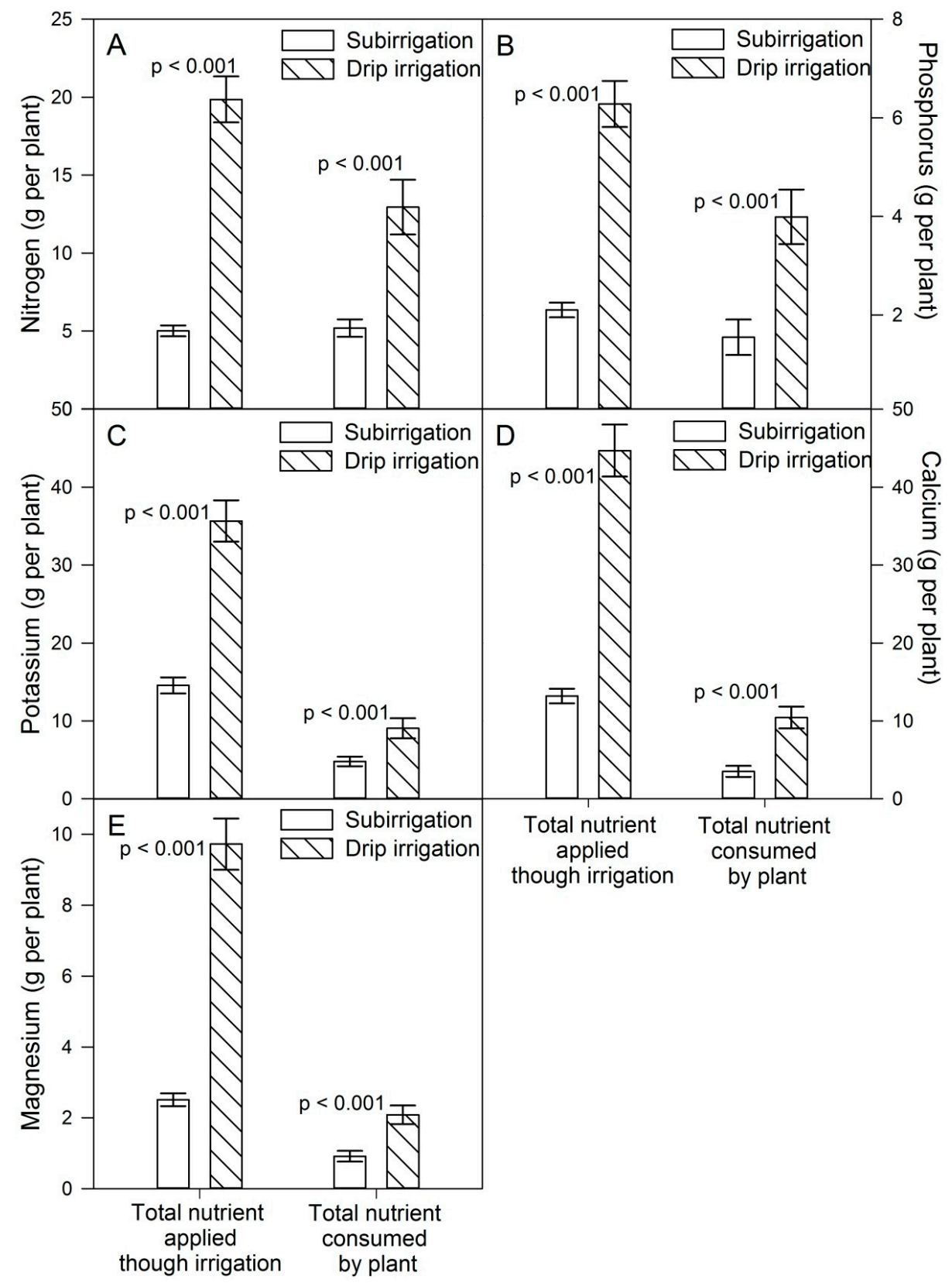

Figure 4. Nitrogen (A), phoshorus (B), potassium (C), calcium (D) and magnesium (E) use efficiency in terms of total nutrients applied though irrigation and nutrients consumed by containerized tomato (Solanum lycopersicon L.) plants grown in two irrigation systems. Means were significantly different according to ANOVA.

\section{Discussion}

In the present study, subirrigation resulted in a 9.5\% reduction in fresh fruit yield compared to drip irrigation. In addition, there was also a $16 \%$ reduction in total dry weight, with roots $(-23.1 \%)$ and 
leaves $(-19.3 \%)$ being more sensitive to dry weight reduction than stems $(-8.1 \%)$ and fruits $(-8.9 \%)$. Substrate $\mathrm{pH}$ and EC were affected by the irrigation system; in general, $\mathrm{pH}$ was lower while EC was higher in subirrigated substrates. Nonetheless, our measurements were much lower than those reported in other studies. For example, in subirrigated containerized tomato, the substrate $\mathrm{pH}$ and EC reported by García-Santiago et al. [39] were, on average, 4.37 and $15.5 \mathrm{dS} \mathrm{m}^{-1}$, respectively, while we are reporting an average $\mathrm{pH}$ of 6.65 and $\mathrm{EC}$ of $2.33 \mathrm{dS} \mathrm{m}^{-1}$. The lower measurements we obtained must be because we used a progressive reduction in the concentration of the nutrient solution, as we started with solutions whose EC was $2.4 \mathrm{dS} \mathrm{m}^{-1}$ at the beginning of the study, whereas at experiment termination it was decreased to $1.2 \mathrm{dS} \mathrm{m}^{-1}$.

The increased substrate EC in subirrigation has been ascribed to the zero-leaching system, the unidirectional flow of the nutrient solution by capillary force, the evapotranspiratory environmental demand and the nutrient solution concentration [31,40,41]. In order to avoid dangerous EC levels, García-Santiago et al. [39] suggested that the concentration of the nutrient solution has to be decreased to a point in which plant nutrient demands are met but salt buildup, and thus substrate EC, is kept to a minimum. The more acidic $\mathrm{pH}$ observed in the substrate in subirrigation is consistent with reports by Martinetti et al. [42] in eggplant (Solanum melongena L.), which has been ascribed to the accumulation of $\mathrm{H}^{+}$in the substrate due to the zero leaching in subirrigation systems [43].

Previous research has shown contradictory results as to the effect of subirrigation on the yield of vegetable species. Santamaria et al. [33] reported that cherry tomato (Solanum lycopersicon var. Cerasiforme Alef., 'Naomi') fruit production decreased by $20 \%$ in subirrigation compared to drip irrigation, while, according to Bouchaaba et al. [2], in green bean (Phaseoulus vulgaris L. 'Saporro') plants the decrease in subirrigation was 33\%. The reduced growth and yield in subirrigation has been attributed to the higher EC recorded in the top layer of the root ball due to salt buildup throughout the growing season, as corroborated in the present study, and to a poor distribution of moisture at each layer $[2,28,40,42]$. Nonetheless, according to other researchers, this does not necessarily affect plant growth since root development occurs mainly on the bottom layer [44], so roots are not exposed to the high EC [44]. In contrast, other reports have shown increased yield by subirrigation of vegetables when compared to that obtained with surface irrigation; for example, García-Santiago et al. [39] reported a $12 \%$ increase in fruit yield in subirrigated tomato plants.

In the present study, tomato fruit production was decreased in subirrigated plants; however, the effect was only marginal as drip-irrigated plants had a yield only $9.5 \%$ higher. This suggests that the benefits of subirrigation can be valuable, because with such an irrigation system there was a higher water and fertilizer use efficiency with minimal impact on fruit yield. Our results showed that water use efficiency was $22 \mathrm{~L}$ of nutrient solution required to produce $1 \mathrm{~kg}$ of fresh tomato fruit in subirrigated plants. In contrast, drip-irrigated plants demanded $86 \%$ more water. In terms of total water consumed by plants, water use efficiency in subirrigation was $76 \mathrm{~L}$ per plant, while drip-irrigated plants demanded $103 \%$ more water. The lower water use efficiency in drip irrigation may be associated with the nutrient solution that leaches at every irrigation event, the more frequent irrigation events required and the higher amounts of nutrient solution required at every irrigation event to saturate the substrate. Garcia-Santiago et al. [39] reported that in subirrigated tomatoes, the substrate had higher total water, easily available water and non-easily available water than in the substrate of drip-irrigated plants at the end of the growing season, resulting in a higher water retention capacity and thus less irrigation events being required than in drip irrigation.

Our data are consistent with those reported by Nederhoff and Stanghellini [21] as tomato plants irrigated with an open system demanded $53 \mathrm{~L}$ to obtain $1 \mathrm{~kg}$ of fresh fruits, while in a recirculation subirrigation system, plants needed $22 \mathrm{~L}$ to produce $1 \mathrm{~kg}$ of fresh fruits. Similarly, testing on eggplants, Martinetti et al. [42] reported a 32\% reduction in the nutrient solution supply, although water use efficiency was similar in both subirrigation and drip irrigation systems as plants required 46.6 and $45.5 \mathrm{~L}$ of nutrient solution to produce $1 \mathrm{~kg}$ of fresh eggplant fruits, respectively. 
In addition to the substantial improvement in water use efficiency, subirrigation allowed significant increases in fertilizer use efficiency. In the present study, there was a higher efficiency in $\mathrm{N}, \mathrm{P}, \mathrm{K}, \mathrm{Ca}$ and $\mathrm{Mg}$ in subirrigated plants compared to drip-irrigated plants. This was because, considering the sum of all the nutrients applied in all the irrigations performed during the experiment, in subirrigation $5.00 \mathrm{~g}$ of $\mathrm{N}$ was applied per plant, while for $\mathrm{P}, \mathrm{K}, \mathrm{Ca}$ and $\mathrm{Mg}$ it was 2.10, 14.55, 13.19 and $2.51 \mathrm{~g}$ per plant, respectively. In contrast, in drip irrigation $19.85 \mathrm{~g}$ of $\mathrm{N}$ was applied per plant, while for $\mathrm{P}, \mathrm{K}, \mathrm{Ca}$ and $\mathrm{Mg}$ it was 6.28, 35.65, 44.68 and $9.72 \mathrm{~g}$ per plant, respectively. The higher nutrient efficiency of the subirrigation system was due to the zero nutrient solution leaching and the less frequent irrigation events required. Parra et al. [45] mentioned that, in tomato, water and nutrient savings were remarkable $(32 \%$ to $45 \%)$ when the nutrient solution was recirculated, although yield was decreased. In contrast, Oztekin et al. [46] reported that there were no differences in tomato fruit yield between closed and open irrigation systems, although there was a significant fertilizer saving with recirculation. Our data are consistent with those reported by Martinetti et al. [42] in subirrigated eggplant as they reported $91 \%$ fertilizer use efficiency when plants were grown in a subirrigation system, while in drip irrigation it was an efficiency of $79 \%$.

The higher nutrient efficiency in subirrigation may also be due to the fact that plants grown under such a system are $16.5 \%$ lower in total dry weight compared to drip-irrigated plants; thus, such plants met their demands with lower nutrient contents, as they accumulated $60 \%, 61 \%, 47 \%, 66 \%$ and $56 \%$ lower N, P, K, Ca and Mg in plant tissues, respectively. Nonetheless, this reduced growth of subirrigated plants did not markedly impact fruit yield, which is in agreement with reports by Massa et al. [10], concluding that any fertigation strategy, such as recirculation of the nutrient solution, is capable of reducing fertilizer use without reducing yield, and therefore has a very promising effect on crop profitability. Blessington-Haley and Reed [30] also showed that subirrigation of several ornamental plants resulted in a K efficiency twice as high of that of surface-irrigated plants.

\section{Conclusions}

Subirrigation proved to be more water- and nutrient-efficient compared to the drip irrigation system for soilless greenhouse tomato production. The higher efficiency is due to the zero leaching of the nutrient solution, the lower number of irrigation events required and the lower nutrient demand of plants, with marginal impact on fruit yield.

Author Contributions: Data curation, L.A.V.-A.; Formal analysis, M.C.-Z.; Funding acquisition, L.A.V.-A.; Investigation, A.M.-C., L.A.V.-A. and M.C.-Z.; Methodology, A.M.-C. and D.A.-C.; Project administration, L.A.V.-A.; Resources, J.A.H.-M.; Software, J.A.G.-F.; Supervision, L.A.V.-A., J.A.H.-M. and D.A.-C.; Visualization, M.C.-Z. and D.A.-C.; Writing-original draft, A.M.-C.; Writing-review and editing, M.C.-Z. and J.A.G.-F. All authors have read and agreed to the published version of the manuscript.

Funding: This research received no external funding.

Acknowledgments: The authors thank the National Council of Science and Technology of Mexico (CONACYT) for supporting Ariel Méndez Cifuentes' Ph.D. Scholarship and the Universidad Autónoma Agraria Antonio Narro for supporting this research.

Conflicts of Interest: The authors declare no conflict of interest.

\section{References}

1. Oki, T.; Quiocho, R.E. Economically challenged and water scarce: Identification of global populations most vulnerable to water crises. Int. J. Water Resour. Dev. 2020, 36, 416-428. [CrossRef]

2. Bouchaaba, Z.; Santamaria, P.; Choukr-Allah, R.; Lamaddalena, N.; Montesano, F.F. Open-cycle drip vs closed-cycle subirrigation: Effects on growth and yield of greenhouse soilless green bean. Sci. Hortic. 2015, 182, 77-85. [CrossRef]

3. Jacobsen, S.E.; Jensen, C.R.; Liu, F. Improving crop production in the arid Mediterranean climate. Field Crop. Res. 2012, 128, 34-47. [CrossRef] 
4. Frija, A.; Cebil, A.; Speelman, S.; Buysse, J.; Huylenbroeck, G.V. Water use and technical efficiencies in horticultural greenhouses in Tunisia. Agric. Water Manag. 2009, 96, 1509-1516. [CrossRef]

5. Rosegrant, M.; Cai, X.; Cline, S. Water and Food to 2025; IFPRI and IWMI Report. 2020 Vision Document; International Food Policy Research Institute: Washington, DC, USA, 2002.

6. FAO. The State of the World's Land and Water Resources for Food and Agriculture (SOLAW)-Managing Systems at Risk; Food and Agriculture Organization of the United Nations, Rome and Earthscan: London, UK, 2011; Available online: http://www.fao.org/water/es/. http://www.fao.org/3/i1688e/i1688e.pdf; (accessed on 14 March 2020).

7. Rosegrant, M.W.; Ximing, C.; Cline, S.A. Water and Food to 2025; Policy Responses to the Threat of Scarcity; International Food Policy Research Institute: Washington, DC, USA, 2002; Available online: http://www.ifpri.org/pubs/ib/ib13.pdf (accessed on 1 April 2020).

8. Arreguín Cortés, F.I.; López Pérez, M.; Marengo Mogollón, H. Mexico's Water Challenges for the 21st Century. In Water Resources in Mexico: Scarcity, Degradation, Stress, Conflicts, Management, and Policy Hexagon Series on Human and Environmental Security and Peace; Oswald Spring, Ú., Ed.; Springer: Berlin/Heidelberg, Germany, 2011; pp. 21-38. [CrossRef]

9. Pardossi, A.; Tognoni, F.; Incrocci, L. Mediterranean greenhouse technology. Chron. Hortic. 2004, 44, $28-34$.

10. Massa, D.; Incrocci, L.; Maggini, R.; Carmassi, G.; Campiotti, C.A.; Pardossi, A. Strategies to decrease water drainage and nitrate emission from soilless cultures of greenhouse tomato. Agric. Water Manag. 2010, 97, 971-980. [CrossRef]

11. Montesano, F.; Parente, A.; Santamaria, P. Closed cycle subirrigation with low concentration nutrient solution can be used for soilless tomato production in saline conditions. Sci. Hortic. 2010, 124, 338-344. [CrossRef]

12. Rouphael, Y.; Colla, G.; Battistelli, A.; Moscatello, S.; Proietti, S.; Rea, E. Yield, water requirement, nutrient uptake and fruit quality of zucchini squash grown in soil and closed soilless culture. J. Hortic. Sci. Biotechnol. 2004, 79, 423-430. [CrossRef]

13. Molitor, H.D. The European perspective with emphasis on subirrigation and recalculation of water and nutrients. Acta Hortic. 1990, 272, 165-173. [CrossRef]

14. McAvoy, R.; Brand, M.; Corbett, E.; Bartok, J., Jr.; Botacchi, A. Effect of leachate fraction on nitrate loading to the soil profile underlying a greenhouse crop. J. Environ. Hortic. 1992, 10, 167-171.

15. Zheng, Y.; Graham, T.H.; Richard, S.; Dixon, M. Potted gerbera production in a subirrigation system using low-concentration nutrient solutions. HortScience 2004, 39, 1283-1286. [CrossRef]

16. Chen, J.; Huang, Y.; Caldwell, R.D. Best management practices for minimizing nitrate leaching from container-grown nurseries. Sci. World J. 2001, 1, 96-102. [CrossRef] [PubMed]

17. Ferrarezi, R.S.; Van Iersel, M.W. Monitoring and controlling subirrigation with soil moisture sensors: A case study with hibiscus. In Proceedings of the SNA Research Conference, Oak Grove, VA, USA, 11 August 2011; Volume 56, pp. 187-191.

18. Richards, D.L.; Reed, D.W. New Guinea impatiens growth response and nutrient release from controlled-release fertilizer in a recirculating subirrigation and top-watering system. HortScience 2004, 39, 280-286. [CrossRef]

19. Santamaria, P.; Serio, F. Coltivazione a ciclo chiuso: La subirrigazione in canaletta. Inf. Agrar. 2001, 41, 45-49.

20. Whitcher, C.L.; Kent, M.W.; Reed, D.W. Phosphorus concentration affects New Guinea impatiens and vinca in recirculating subirrigation. HortScience 2005, 40, 2047-2051. [CrossRef]

21. Nederhoff, E.; Stanghellini, C. Water Use Efficiency of Tomatoes. Pract. Hydroponics Greenh. 2010, 115, 52-59.

22. Deligios, P.A.; Chergia, A.P.; Sanna, G.; Solinas, S.; Todde, G.; Narvarte, L.; Ledda, L. Climate change adaptation and water saving by innovative irrigation management applied on open field globe artichoke. Sci. Total Environ. 2019, 649, 461-472. [CrossRef]

23. Putra, P.A.; Yuliando, H. Soilless culture system to support water use efficiency and product quality: A review. Agric. Agric. Sci. Procedia 2015, 3, 283-288. [CrossRef]

24. Savvas, D.; Gianquinto, G.; Tuzel, Y.; Gruda, N. Soilless Culture. FAO Plant Production and Protection; Paper No. 217. Good Agricultural Practices for Greenhouse Vegetable Crops; FAO: Rome, Italy, 2013; pp. 303-354.

25. Burrage, S.W. Soilless culture and water use efficiency for greenhouses in arid, hot climates. In International Workshop on Protected Agriculture in the Arabian Peninsula, Doha, Qatar; Moustafa, A.T., Al-Mohammadi, A., Abou-Hadid, A., Peacock, J.M., Eds.; ICARDA: Aleppo, Syria, 1998; pp. 64-70. 
26. Bumgarner, M.L.; Salifu, K.F.; Jacobs, D.F. Subirrigation of Quercus rubra seedlings: Nursery stock quality, media chemistry, and early field performance. HortScience 2008, 43, 2179-2185. [CrossRef]

27. Majsztrik, J.C.; Ristvey, A.G.; Lea-Cox, J.D. 7 Water and nutrient management in the production of container-grown ornamentals. Hortic. Rev. 2011, 38, 253-297.

28. Rouphael, Y.; Colla, G. Growth, yield, fruit quality and nutrient uptake of hydroponically cultivated zucchini squash as affected by irrigation systems and growing seasons. Sci. Hortic. 2005, 105, 177-195. [CrossRef]

29. Gent, M.P.; McAvoy, R.J. Water and nutrient uptake and use efficiency with partial saturation ebb and flow watering. HortScience 2011, 46, 791-798. [CrossRef]

30. Blessington-Haley, T.; Reed, D.W. Optimum potassium concentrations in recirculating subirrigation for selected greenhouse crops. HortScience 2004, 39, 1441-1444. [CrossRef]

31. Incrocci, L.; Malorgio, F.; Della, B.A.; Pardossi, A. The influence of drip irrigation or subirrigation on tomato grown in closed-loop substrate culture with saline water Italy. Sci. Hortic. 2006, 107, 365-372. [CrossRef]

32. Serio, F.; Elia, A.; Signore, A.; Santamaria, P. Influence of nitrogen form on yield and nitrate content of subirrigated early potato. J. Sci. Food Agric. 2004, 84, 1428-1432. [CrossRef]

33. Santamaria, P.; Campanile, G.; Parente, A.; Elia, A. Subirrigation vs. drip-irrigation: Effects on yield and quality of soilless grown cherry tomato. Italy. J. Hortic. Sci. Biotechnol. 2003, 78, 290-296. [CrossRef]

34. Bremner, J.M. Nitrogen-total. In Methods of Soil Analysis. Part 3. Chemical Methods; Sparks, D.L., Ed.; Soil Science Society of America: Madison, WI, USA, 1996; Volume 5, pp. 1085-1121.

35. Soltanpour, P.N.; Johnson, G.W.; Workman, S.M.; Jones, J.B.; Miller, R.O. Inductively coupled plasma emission spectrometry and inductively coupled plasma mass spectrometry. In Methods of Soil Analysis. Part 3. Chemical Methods; Sparks, D.L., Ed.; Soil Science Society of North America: Madison, WI, USA, 1996; pp. 91-139.

36. Warncke, D.D.; Krauskopf, D.M. Greenhouse Growth Media: Testing and Nutrition Guidelines. Ext. Bul. E; Mich. State Univ. Coop. Ext. Ser.: Lansing, MI, USA, 1983; Volume 176.

37. R. Core Team R: A Language and Environment for Statistical Computing. Version 2.3.4. 2009. Available online: https://www.r-project.org/,https://rstudio.com/ (accessed on 22 August 2017).

38. Mendiburo, F.D. Agricolae: Statistical Provedores for Agricultural Research. R Package Agriculture Package Version 1.2.8. 2017. Available online: https://cran.r-project.org/web/packages/agricolae/index.html (accessed on 22 August 2017).

39. García-Santiago, J.C.; Valdez-Aguilar, L.A.; Cartmill, A.D.; Cartmill, D.L.; Juárez-López, P.; Díaz-Pérez, J.C. Subirrigation of Container-Grown Tomato I: Decreased concentration of the nutrient solution sustains growth and yield. Water 2019, 11, 2064. [CrossRef]

40. Cox, D.A. Growth, nutrient content, and growth medium electrical conductivity of poinsettia irrigated by subirrigation or from overhead. USA J. Plant Nutr. 2001, 24, 523-533. [CrossRef]

41. Rouphael, Y.; Cardarelli, M.; Rea, E.; Colla, G. The influence of irrigation system and nutrient solution concentration on potted geranium production under various conditions of radiation and temperature. Sci. Hortic. 2008, 118, 328-337. [CrossRef]

42. Martinetti, L.; Ferrante, A.; Quattrini, E. Effect of drip or subirrigation on growth and yield of Solanum melongena L. in closed systems with salty water. Res. J. Biol. Sci. 2008, 3, 467-474.

43. Kent, M.W.; Reed, D.W. Nitrogen nutrition of New Guinea impatiens 'Barbados' and spathiphyllum Petite' in a subirrigation system. J. Am. Soc. Hortic. Sci. 1996, 121, 816-819. [CrossRef]

44. Morvant, J.K.; Dole, J.M.; Allen, E. Irrigation systems alter distribution of roots, soluble salts, nitrogen, and $\mathrm{pH}$ in the root medium. HortTechnology 1997, 7, 156-160. [CrossRef]

45. Parra, M.; Raya, V.; Cid, M.C.; Haroun, J. Alternative to tomato soilless culture in open system in the Canary Islands: Preliminary results. Acta Hortic. 2008, 807, 509-514. [CrossRef]

46. Oztekin, G.B.; Tüzel, Y.; Tüzel, I.H.; Meric, K.M. Effects of EC levels of nutrient solution on tomato crop in open and closed systems. Acta Hortic. 2007, 801, 1243-1250. [CrossRef]

(C) 2020 by the authors. Licensee MDPI, Basel, Switzerland. This article is an open access article distributed under the terms and conditions of the Creative Commons Attribution (CC BY) license (http://creativecommons.org/licenses/by/4.0/). 